\title{
Mergers Of Private Enterprises: A Powerful Force For The Development Of Private Business Organizations In Latin America - The Case Of Ecuador
}

\author{
John Theodore, Warner University, USA
}

\begin{abstract}
The purpose of this article was to assess the scale of mergers of small and medium-size private business organizations in Ecuador over the past ten years and to determine if the ownership and management of such enterprises have the desire in merging with other Ecuadorian business organizations. Such mergers create larger business enterprises that allow the appearance, sustenance, and development of the principles of organization and precipitate the need for commensurate managerial education for their management and ownership. It was determined, in this study, that only a very limited number of mergers have taken place during the past ten years and that the entrepreneurial mindset of business owners and their managers is not favoring mergers. The ownership and management of small and medium-size Ecuadorian business organizations do not understand the benefits derived from mergers. The study noted that Ecuador's business owners and their managers are traditionally accustomed to operating with obsolete management methods and controls that suppress opportunities leading to organizational development.
\end{abstract}

Keywords: Organization development; microeconomic development; organization size; organizational structure; organizational levels; departmentalization; delegation; span of control; chain and line of command; managerial education; mergers; PYMES; strategic alliances

\section{INTRODUCTION}

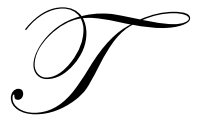

he current Ecuadorian President, Rafael Correa, is favoring a socialist and macroeconomic model of economic development, whereas the private sector is supporting a microeconomic approach. Correa's economic plan of 2007-2010 proposes to achieve economic revitalization through social justice and freedom under the auspices of the government (Luna Osorio, 2007). Ecuador's private sector favors a free-market approach whose infrastructure is predicated on the productivity, performance, and competitiveness of the country's private enterprises. Proponents of an economy based on the free market system claim this classic form of economics will be conducive to the development of all economic factors, especially the human one, because it provides and sustains freedom (Lucio-Paredes, 2008).

The author of this work has produced a series of articles - the current article is the third in the seriesabout the present status of small private business organizations in the Ecuadorian economy (Theodore, 2009). The first article identified and evaluated the prerequisites needed in Ecuador's private enterprises that are conducive to economic development to ascertain if a free-market microeconomic approach to economic development is feasible at the present time. In order for private enterprises to reach a level of effective and efficient performance, they need to meet certain important prerequisites. According to the writer's Holistic Management model (Theodore, 2003), such prerequisites start with an ample organizational size, a situation that allows the formation of a well-constructed and viable organizational structure with three hierarchal levels and sufficient departmentalization. All of the above conditions permit the formation, sustenance, and development of the chain and unity of command, span of control, 
and delegation which, when integrated with the organizational structure, organizational levels, and departmentalization, form the infrastructure for organizational development.

Organizational development is a planned change effort which involves all the parts of the organization (Schein 1988). It is initiated and managed from the top hierarchy of the system and it is designed to increase organizational effectiveness. The ultimate goal of organization development is to make the organization more open and more adaptive through increases in capability and potential so it can continue to make such planned change efforts on an action orientation basis (Theodore, 2002).

It was concluded that Ecuadorian private enterprises are not currently in a position to contribute toward economic development because the Ecuadorian economy is composed of a very large number of private organizations of small size. Small and medium-sized enterprises constitute $97 \%$ of all enterprises in the country (Vasquez \& Santos, 2008). This factor is a tremendous impediment toward the creation of a critical mass of appropriately sized organizations - a minimum of 30 employees and managers-- that can utilize the abovementioned organizational structures. Ecuador's private sector is characterized by enterprises that typically employ small numbers of family members who function both as managers and employees. The average number of persons employed is three (Hurtado, 2007). The small size and proliferation of family owned and managed enterprises (and consequently the traditional hierarchal, rigid structure) have impeded their economic development and modernization of management techniques.

Two immediate actions have been offered to ownership and management of such enterprises: (1) conduct mergers that will precipitate larger organizational size (Arosemena, 2007), and (2) provide advanced management education for private enterprise managers and entrepreneurs (owners) managers - both to be identified as managers in this article-- in order for them to be qualified and ready to implement the advanced managerial and organizational practices needed by the newly formed and emerged enterprises (Theodore,1999).

The second articled (Theodore, 2009) dealt with the availability of management education in Ecuador and the usage of it by the management of private enterprises in the country. Management's importance in the economy of a nation is paramount because it is responsible for the success or failure of businesses, which are the foundation stones of the free enterprise system. In turn, one of the most essential prerequisites to effective management is management education because it increases the knowledge, skills, and productivity of managers. The benefits of a better management education are improved ability to identify viable business opportunities; less resources waste on ill-conceived ventures; enhanced competitive edge internationally; improved job satisfaction and retention of personnel; and improved effectiveness in the turbulent external environment.

It was concluded that in the educational sector Ecuadorian private enterprises are not currently in a position to contribute toward economic development because their managers do not have the necessary and commensurate managerial education. In comparison to the total population of Ecuador, university enrollment is relatively low. Recent statistics indicate that less than $18 \%$ of those who are 24 years old and older are formally attending universities or taken class in universities (Ospina Peralta, 2007). Most university professors in Ecuador have an undergraduate degree only. This is very evident in the area of business administration. Fewer than four percent of them have a doctoral degree which, most cases, is not related to business curricula (Haar \& Price, 2008). Most of the managers who have university education have degrees in law, engineering, and finance; not in management. Studies in management require a change in the mentality of the Ecuadorian managers (Rigail, 2008). Curricula dedicated to educating managers are very limited. Furthermore, managers are also responsible for resisting such education due to cultural and economic reasons (Arosemena, 2007).

\section{MERGERS}

The purpose of this article - the third in the series — was to detect if mergers of small and medium-size business organizations have taken place in Ecuador in the past ten years and if the ownership and management of such enterprises have the interest in merging with other Ecuadorian business organizations. Mergers create larger size business enterprises. a condition which allows the appearance, sustenance, and development of the principles of organization and the need for commensurate management education for the managers of such enterprises, thus 
preparing the merged organizations to attain organizational development.

If organizations cannot grow internally, one of the most common strategies is through mergers and acquisitions. A merger takes place when two or more organizations agree to create a new one whose factors of production are larger than those of the previous organizations. A merger-- usually of similar size--combines the merged organizations' resources to form a new organization (Robins and DeCenzo, 2005). The merging organizations may or may not be of the same size. Acquisitions are very similar to mergers. In acquisitions, organizations also want to increase their factors of production and attain the necessary economies of scale, as is the case with mergers. In acquisitions, one organization buys one or more organizations. The resources, competencies, and competitive capabilities of the newly created entities result much the same whether the combination is the result of acquisition or merger (Thompson, Strickland, \& Gamble, 2005). In the case of Ecuador, mergers and acquisitions are referred to as mergers. There are two major types of mergers: (a) horizontal mergers that have to do with organizations performing the same functions, dealing with the same products, and are in direct competition, such as wholesalers dealing with the same products -- steel pipe and tubing-- and are competing among themselves, and (b) vertical mergers involving organizations that perform different functions but are dealing with the same products, such as producers of steel pipe and tubing, merging with wholesalers of the same products.

Regardless of their structure and category, all mergers and acquisitions are aiming toward increasing their organizations' factors of production, a situation that also entails the increase of their organizational size which is the first step for organizational development.

\section{THE CASE OF ECUADOR}

Ecuadorian law does not restrict mergers. Small and medium-size organizations have the opportunity to merge easily. Large corporations have to go through a more complicated process. A time consuming application is submitted to the Superintedencia de Companias accompanied by a detailed list of the purpose of the merger and a precise accounting documentation of the assets, liabilities, and capital of the new organization. In addition, opening a banking account and becoming member of the respective industry and member of a chamber of commerce are required. There is a long list of additional requirements which are beyond the scope of this article and a detailed description of the work contracts of the personnel of the organization to be filed with the Ministry of Labor (Luis Luna Osorio, 2007).

From 1998 to2008, over 370 mergers of large corporations took place in Ecuador. The percentages per classification of such enterprises were: $25 \%$ commercial, $23 \%$ industrial; $22 \%$ service, $8 \%$ agricultural, $6 \%$ transportation, and 16\% other classifications (Superintendencia de Compañias, 2009). The merger of PYMES (Pequenas y Medias Empresas) — acronym for small and medium-size business_-is almost non-extant.

Substantial research has taken place in the area of the mergers of large Ecuadorian corporations that constitute less than $3 \%$ of all business organizations in the country. Those mergers have resulted to great advantages in all factors of production, have contributed to managerial development, and are competing effectively and efficiently on an international basis (Murillo Moncayo \& Mendez Prado, 2008). These researchers urged PYMES to pursue mergers when possible. Two years earlier another important research took place pertinent to mergers with emphasis upon the merger of Interbrew-Ambev. Here, too, the researchers urged Pymes to pursue mergers (Panchana Pita \& Yong Paraga, 2006).

Mergers of PYMES are almost non-extant in Ecuador. La Superintendencia de Companias has registered a handful of medium-size mergers during the last 20 years. As indicated earlier in this article and in the previous ones in this series, the entrepreneurial mentality of business owners and their managers has remained underdeveloped in Ecuador. They cannot visualize the benefits received as the result of mergers. Mergers can create larger organizational size for the development of the principles of organization and will necessitate the presence of professional managers with commensurate managerial education to operate such enterprises. The ownership and management of PYMES are accustomed to operating with obsolete methods and controls and they are not cognizant of the hidden costs that permeate in their organizations due to diseconomies of scale. Up to $40 \%$ of their sales value is caused by hidden operating costs that are not detected (Arosemena, 2008). 
Carlos Lopez Cerdan Ripoll (2004) has been experimenting with a substantially different way of creating economies of scale for PYMES. He has articulated and integrated a small number of PYMES, mainly on a vertical basis, thus creating pseudo vertical mergers or nano-strategic alliances that have somehow resulted in more profits for the participating organizations. This temporary success has no solid foundations and the participating organizations are not creating internal infrastructures for their growth and development. This is another characteristic of the entrepreneurial and managerial mentality in Ecuador that emphasizes daily profits at the expense of long term growth and development.

\section{CONCLUSIONS AND RECOMMENDATIONS}

Lamentably, until now, mergers of PYMES are almost non-existent. Therefore, the opportunity to create larger size organizations has been missed. Small and medium-size organizations will continue to play the same limited role in the economy of Ecuador and will not be able to allow organizational development to take place. This economic phenomenon will not enable Ecuador's microeconomic development and global competitiveness to take place.

\section{AUTHOR INFORMATION}

John Theodore is the holder of a Ph.D. degree in Administration and Latin American Studies from the University of Kansas; a Ph.D. in Management from the Aristotelian University in Greece, European Union; and a D.B.A. in International Business from the University of South Africa. He has been teaching and consulting for four decades domestically and internationally. $\mathrm{He}$ is a visiting professor in various Latin American universities, including Ecuador. He has been teaching with various national universities, such as NCU, AIU, Warner University, and Kaplan University.

\section{REFERENCES}

1. Arosemena-Arosemena, G. (2008). Hacia la superación gerencial. Industrias. Septiembre, 13(20).

2. Haar,J. \& Price, J. (2008). Can Latin America complete? New York: Palgrave McMillan.

3. Hurtado, O. (2007). El poder político en Ecuador. (17 $\left.{ }^{\mathrm{a}} \mathrm{ed}\right)$. Quito, Ecuador: Editorial Planeta del Ecuador.

4. Lopez Cerdan Ripolli, C. (2004). Aspectos Conceptuales De La Asociatividad Y Cooperación Empresarial De Las Pymes. Taller de Capacitación Sobre Estrategias Taller Estrategias De Cooperación Empresarial Para El Mejoramiento De La Competitividad En Pymes. IBERPYME. Quito, Ecuador.

5. Luna Osorio, L. (2007). Proyección del Ecuador al mundo: 2007-2010. Quito, Ecuador: Pudeleco Editores.

6. $\quad$ Lucio-Paredes, P. (2008). En busca de la constitución perdida. Quito, Ecuador: TRAMA Ediciones.

7. Murillo Moncayo, V. \& Méndez Prado M. (2008) La Fusión de Empresas en el Ecuador como Opción de Crecimiento: Un Análisis de Casos. (2008). Revista Tecnológica ESPOL. Volumen XX. Guayaquil, Ecuador.

8. Ospina Peralta, P. (2007). Nuestro Ecuador. Manual de realidad nacional. Quito, Ecuador: Universidad Andina Simón Bolívar.

9. Panchana Pita, V. \& Yong Paraga, C. (2006) Estudio De Fusiones Y Adquisiciones Y Sus Efectos En Retornos Del Accionista: Caso Interbrew-Ambev. Guayaquil, Ecuador. Escuela Superior Politécnica Litoral.

10. Rigail, A (2008). La mentalidad de la abundancia. Arco Consultores.5, 4-8

11. Robins, S. R. \& DeCenzo, D. (005). Fundamentals of Management. (5th ed). Upper Saddle River, New Jersey: Prentice Hall.

12. Schein, E., H. (1988). Process consultation, Vol. 1: Its role in organization development. (2nd ed) Reading, Mass: Addison-Wesley Publishing Company.

13. Superintendencia de Companias. (2008). Las 1000 Mas Grandes Companias de Ecuador. Quito, Ecuador.

14. Theodore, J. (2004). Desarrollo de organizaciones: una apuesta a la eficiencia. Ekos, Junio, 125-130.

15. Theodore, J.D. (2009). Organizational size: A key element in the development of private enterprises in the less developed countries. The case of Ecuador. International Journal of Business \&Economics Research July, 8, (7), 45-49.

16. Theodore, J. (2003). Holistic management. EAN. 47, Enero-Abril 122-136. 
17. Theodore, J. (2002). Organization Development: Target Areas and Goals for Planned Change Interventions. The New Zealand Institute of Management, March-April 52-65

18. Theodore, J (1999). The impact of religious, social, and economic forces upon the development of management education in Latin America. Journal of Third World Studies. 16, (2), 133-139.

19. Theodore, J.D. (2010). Management education: A key element for the development of private enterprises in Latin America: The case of Ecuador.International Business \& Economics Research Journal. Volume 9, Number 2.

20. Thompson, A., Strickland, A.J. \& Gamble, L. (2005). Crafting and Executing Strategy. Boston: McGrawHill Irwin.

21. Vásquez, Lola \& Napoleón Santos (2008). Ecuador: Su realidad. Quito, Ecuador. Fundación de investigación y promoción social "José Peralta" 
NOTES 